\title{
Biogas Digestate in Vegetable Hydroponic Production: pH Dynamics and pH Management by Controlled Nitrification
}

\author{
Olle Pelayo Lind ${ }^{1} \cdot$ Malin Hultberg $^{1} \cdot$ Karl-Johan Bergstrand $^{1} \cdot$ Helene Larsson-Jönsson ${ }^{1} \cdot$ Siri Caspersen $^{1}$. \\ Håkan Asp ${ }^{1}$ D
}

Received: 2 September 2019 / Accepted: 5 February 2020 / Published online: 13 February 2020

(c) The Author(s) 2020

\begin{abstract}
Soilless cultivation of vegetables with digestate fertilizer from biogas production as a nutrient source is a promising method for integrating food production and organic waste management. In this study, bok choy (Brassica rapa var. chinensis) was cultivated in a hydroponic nutrient film technique system with biogas digestate as the only fertilizer source. Nitrification in moving bed biofilm reactors (external and/or integrated into the hydroponic cultivation system) was employed to lower the high ammonium concentration in the digestate prior to use. Treatments with differing nitrification and digestate input strategies were compared with respect to $\mathrm{pH}$ dynamics, crop growth, shoot water content, and shoot mineral content. The results showed that $<20 \%$ longer cultivation time $(<1 \mathrm{week})$ gave similar yield in biogas digestate-based hydroponics as in conventional hydroponics based on synthetic fertilizers. Automatic $\mathrm{pH}$ control through addition of digestate resulted in similar shoot dry weight as in the mineral fertilizer reference system. It can be concluded that biogas digestate is a suitable plant nutrient source for hydroponic production of bok choy, considering productivity and circularity aspects. The combined impact of digestate ammonium content, digestate $\mathrm{pH}$, and the nitrification step needs to be considered when designing a hydroponic system with biogas digestate as the fertilizer source.
\end{abstract}

\section{Graphic Abstract}

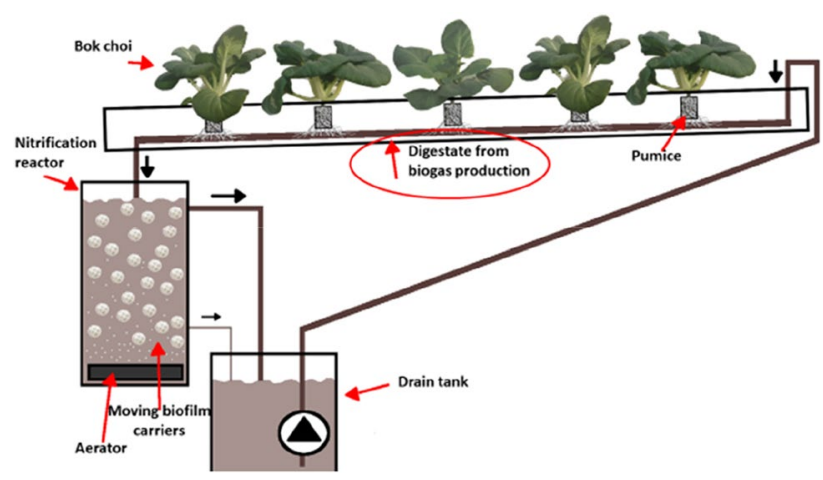

Keywords Anaerobic digestate $\cdot$ Biogas production $\cdot$ Biofertilizer $\cdot$ Circular economy $\cdot$ Organic hydroponics

\section{Abbreviations}

BD Biogas digestate

EC Electrical conductivity

Håkan Asp

hakan.asp@slu.se

1 Department of Biosystems and Technology, Swedish

University of Agricultural Sciences, P.O. Box 103,

23053 Alnarp, Sweden
MBBR Moving bed biofilm reactor

NFT Nutrient film technique 


\section{Statement of Novelty}

Biogas production is an important part of the bio based economy in several areas. The residue, digestate, from this production is commonly spread on agricultural fields. This nutrient rich digestate can be more efficiently used e.g. as a nutrient source in highly productive hydroponic cultivation systems. High ammonium concentrations and varying $\mathrm{pH}$ are obstacles for a successful use of the digestate. We combine techniques for the crucial nitrification step with $\mathrm{pH}$ management showing that this can be an effective way to manage the hydroponic production system.

\section{Introduction}

In order to avoid linear use of natural resources, a circular bioeconomy approach is needed to integrate organic waste management and food production [1-3]. Anaerobic biodigestion fits well into the principles of a circular bioeconomy, as it allows for efficient production of storable energy, through biogas production, and fertilizer, the biogas digestate (BD), from organic waste [3-6].

One major obstacle to increased production of biogas is the high water content of $\mathrm{BD}$ and the associated high costs for its transportation [7, 8]. High production of organic waste in urban areas and lack of nearby agricultural land of sufficient area impede the expansion and profitability of biogas and BD production [9]. The seasonality of agricultural production in temperate climates also complicates the digestate disposal issue in year-round production [10].

Through soilless production, high crop yields can be achieved irrespective of availability of arable land [11, 12]. If conducted in a controlled environment, soilless cultivation also allows for food production independent of external climate factors [13, 14]. Thus, food production from soilless cultivation and controlled environment agriculture can supply a platform for higher biogas and BD production in cases where arable soil scarcity, seasonality, and transportation cost to agricultural fields are limiting factors.

The majority of food production in soilless cultivation is currently performed using synthetic fertilizers. However, use of organic inputs in soilless systems has been shown to be potentially feasible for food production, in e.g., aquaponic systems, systems with inputs of mineralized organic fertilizers and wastes from fish production, and systems with inputs of BD [15-19]. Soilless systems with organic fertilizers differ from conventional systems with synthetic fertilizers in that they are subjected to a nutrient solution of higher complexity in terms of inorganic, organic and microbial content. The dynamics and control of standard cultivation variables in soilless cultivation, e.g., $\mathrm{pH}$ and electrical conductivity (EC), needs to be studied specifically for such systems.

Hydroponics is generally defined as soilless production in which all plant nutrients are provided in the nutrient solution [20]. When using BD for hydroponic production, high concentration of ammonium $\left(\mathrm{NH}_{4}^{+}\right)$in the digestate is a problem. A commonly used approach to deal with this is to nitrify the ammonium into nitrate $\left(\mathrm{NO}_{3}{ }^{-}\right)$, in order to avoid toxic levels of ammonium for the plants and to obtain an appropriate ammonium:nitrate ratio for optimized yield and desired crop quality [15, 21, 22].

In hydroponic production, control of $\mathrm{pH}$ is of great importance in order to maintain a well-functioning system with high availability of nutrients. The $\mathrm{pH}$ dynamics in hydroponic cultivation systems using BD are affected by both nitrification and plant uptake of nitrogen. Plant uptake of nitrate-nitrogen leads to exudation of carbonate ions $\left(\mathrm{CO}_{3}{ }^{2-}\right)$ and hydroxide $\left(\mathrm{OH}^{-}\right)$, increasing the $\mathrm{pH}$ in the nutrient solution [23]. Addition of BD to a soilless system leads to an immediate $\mathrm{pH}$ increase, due to the high $\mathrm{pH}$ of BD [7], but plant uptake of ammonium subsequently leads to proton $\left(\mathrm{H}^{+}\right)$excretion from the roots, and thus decreased $\mathrm{pH}$ in the nutrient solution [23]. Nitrification also leads to a $\mathrm{pH}$ decrease, due to oxidation of ammonium to nitrite $\left(\mathrm{NO}_{2}^{-}\right)$, and nitrite to nitrate [24]. Due to this complexity, it is evident that knowledge of $\mathrm{pH}$ control in systems using $\mathrm{BD}$ is essential for optimized yield.

In the present study, the $\mathrm{pH}$ dynamics in hydroponic cultivation of bok choy (Chinese cabbage) with BD as only plant nutrient source were examined in set-ups with external and/or integrated nitrification bioreactors. In addition, the impact of input of nitrified or untreated digestate was compared. The BD treatments were compared against a reference treatment using a conventional inorganic hydroponic nutrient solution with respect to growth and leaf mineral content.

\section{Materials and Methods}

\section{Plant Material and Growing Conditions}

Seeds of bok choy (Brassica rapa ssp. Chinensis cv. 'Joy Choi', Olsson Seed, Sweden) were sown in 2-8 mm fraction pumice $(\mathrm{Hekla} 囚$, Bara Mineraler, Bara, Sweden) in 5-cm net pots in trays. The plants were subirrigated and were fertilized with half-strength commercial inorganic fertilizer for soilless production after germination $\left(0.5+0.5 \mathrm{~g} \mathrm{~L}^{-1}\right.$, respectively, of Kristalon ${ }^{\mathrm{TM}}$ Indigo and Calcinit ${ }^{\mathrm{TM}}$; Yara, Oslo, Norway). Seedlings with 3-4 true leaves were transplanted to a nutrient film technique (NFT) system 21 days after sowing, by placing the net pots into NFT gullies (Fig. 1). 


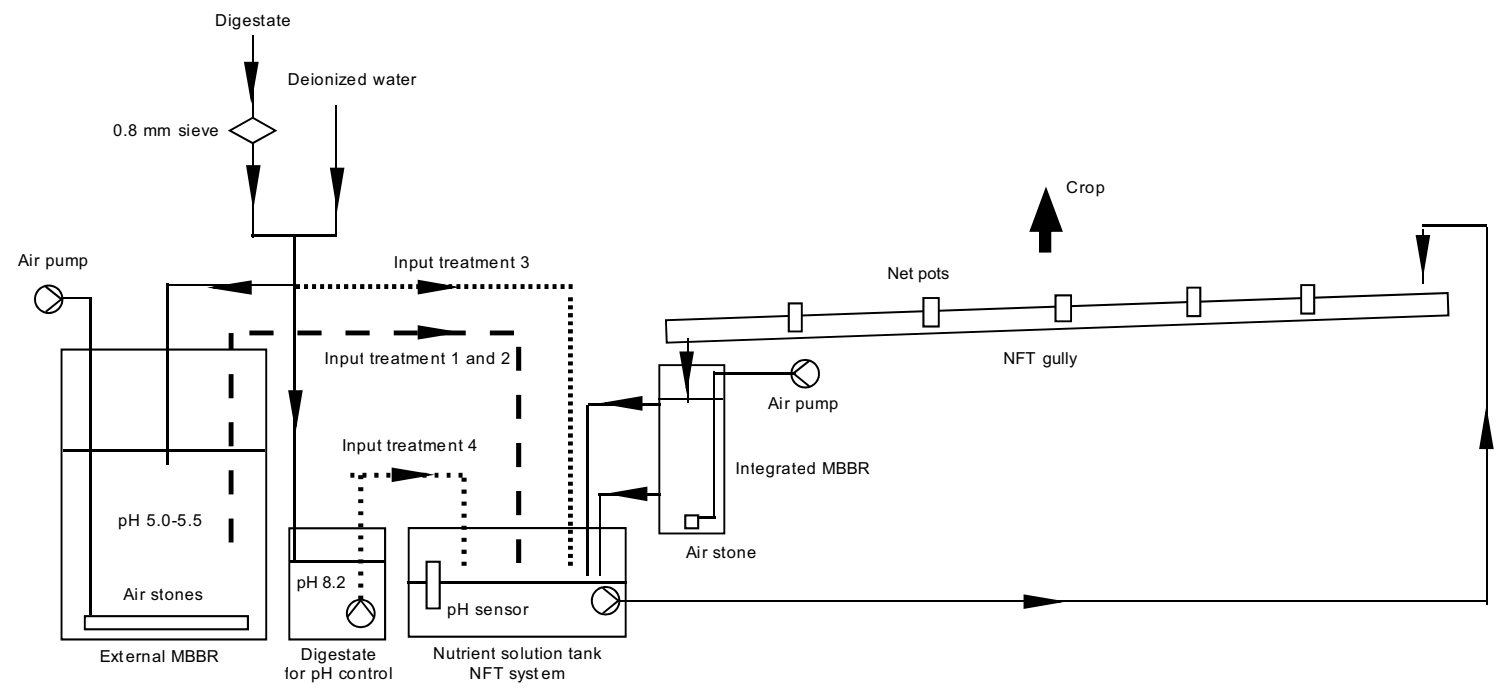

Fig. 1 Set-up of the hydroponic nutrient film technique (NFT) system and integrated moving bed biofilm reactor (MBBR)

The NFT system consisted of $1612-\mathrm{cm}$ gullies with five net pots per gully, with a planting spacing of $25 \mathrm{~cm}$ within rows and $40 \mathrm{~cm}$ between rows. Each gully represented a separate system and four replicate gullies were used per treatment. Channel slope was $1.8 \%$ and flow rate was 3.5 $\mathrm{L} \mathrm{min}^{-1}$. This high flow rate was used in order to avoid settling of solids in the gullies. The minimum tubing/nozzle dimension in the recirculating system was $12.7 \mathrm{~mm}$, in order to avoid clogging. The experiments were conducted in the period October-February in a greenhouse chamber at Campus Alnarp of the Swedish University of Agricultural Sciences in southern Sweden. Supplemental lighting, $18 \mathrm{~h} \mathrm{day}^{-1}$, was supplied with high-pressure sodium lamps ( $400 \mathrm{~W}$, Philips, Eindhoven, the Netherlands) and the amount of supplementary light was on average $97 \mu \mathrm{mol} \mathrm{m}^{-2} \mathrm{~s}^{-1}$, corresponding to a daily light integral of $6.3 \mathrm{~mol} \mathrm{~m}^{-2}$. The day/ night temperature was set to $20 / 18{ }^{\circ} \mathrm{C}$, and was controlled through heating and natural ventilation.

\section{Biogas Digestate}

Biogas digestate was collected from the Gasum AB biogas plant Jordberga in southern Sweden. Input substrate to the mesophilic anaerobic digestion process was plant material; crop residues $85.5 \%$ (by weight), plant based residues from food industry $12.5 \%$ and iron chloride $2 \%$. Retention time in the biogas reactors was 80 days. Untreated BD had a dry matter content of $7.3 \%$ and an ammonium-nitrogen content of $2400 \mathrm{mg} \mathrm{L}^{-1}$ [25]. The BD was filtered by sieving through $0.8 \mathrm{~mm}$ mesh and diluted 10 times with deionized water. Pilot growing trials showed that the BD obtained after filtration and dilution still had too high ammonium concentration, hampering plant production.
To avoid ammonium toxicity, the BD used for hydroponic cultivation in the present study was diluted to a concentration of $200 \mathrm{mg}$ ammonium-nitrogen $\mathrm{L}^{-1} \mathrm{BD}$ before use in the main cultivation treatments, where nitrification reduced the ammonium-nitrogen level to below $20 \mathrm{mg} \mathrm{L}^{-1}$ (Table 1).

\section{Nitrification Reactors}

Moving bed biofilm reactors (MBBR) for controlled nitrification of the sieved and diluted digestate were used both before input of BD to NFT systems and for nitrification within the NFT systems during cultivation. In the latter case, the MBBR constituted an integrated part of the recirculating hydroponic system (Fig. 1).

A $100 \mathrm{~L}$ water barrel with $20 \mathrm{~L}$ of K1 biofilm carriers (AnoxKaldnes, Veolia Water Treatment Technologies AB, Sweden) was used as external MBBR for nitrification of 60 $\mathrm{L}$ diluted digestate before use in the NFT systems. Aeration was performed with a $25 \mathrm{~W}$ air pump (V30, Hailea, China). The biofilm carriers in the MBBR had already been inoculated with $2 \mathrm{~L}$ active sludge from a municipal water treatment plant (Källby, Lund, Sweden) in an earlier study.

The integrated MBBR was constructed using $160 \mathrm{~mm}$ diameter PVC pipe containing $2 \mathrm{~L}$ of biofilm carrier and $9 \mathrm{~L}$ of diluted BD. The flow rate through the integrated MBBR was $0.3 \mathrm{~L} \mathrm{~min}^{-1}$ and the retention time in the reactor was $\sim 30 \mathrm{~min}$. Excessive nutrient solution bypassed the reactor through an overflow pipe into the NFT nutrient solution tank (Fig. 1). 
Table 1 Values of $\mathrm{pH}$ and electrical conductivity (EC) and plant nutrient concentrations $\left(\mathrm{mg} \mathrm{L}^{-1}\right)$ in (i) digestate before nitrification, (ii) digestate nitrified in an external moving bed biofilm reactor (MBBR), and (iii) a commercial inorganic reference (Kristalon Indigo $^{\mathrm{TM}}+$ Calcinit $^{\mathrm{TM}}$, Yara $\mathrm{AB}$, Oslo Norway)

\begin{tabular}{lllll}
\hline $\begin{array}{l}\text { Plant nutrients, } \\
\left(\mathrm{mg} \mathrm{L}^{-1}\right)\end{array}$ & $\begin{array}{l}\text { Digestate before } \\
\text { nitrification }\end{array}$ & $\begin{array}{l}\text { Digestate from exter- } \\
\text { nal MBBR }\end{array}$ & $\begin{array}{l}\text { Inorganic } \\
\text { reference }\end{array}$ & $\begin{array}{l}\text { Difference between: } \\
\text { digestate, external } \\
\text { MBBR and Refer- } \\
\text { ence }\end{array}$ \\
\hline $\mathrm{pH}$ & 8.2 & 5.0 & 5.8 & - \\
$\mathrm{EC}\left(\mathrm{mS} \mathrm{cm}^{-2}\right)$ & 2 & 1.8 & 1.8 & - \\
$\mathrm{NH}_{4}-\mathrm{N}$ & 210 & 14 & 16.8 & -2.8 \\
$\mathrm{NO}_{2}-\mathrm{N}$ & $<1$ & 78 & - & 78 \\
$\mathrm{NO}_{3}-\mathrm{N}$ & $<1$ & 90 & 175.2 & -85.2 \\
$\mathrm{Total}$ inorganic N & 210 & 182 & 192 & -10 \\
$\mathrm{P}$ & 38 & 41 & 39.2 & 1.8 \\
$\mathrm{~K}$ & 240 & 250 & 197.6 & 52.4 \\
$\mathrm{Mg}$ & 23 & 21 & 33.6 & -12.6 \\
$\mathrm{~S}$ & - & 27 & 45.6 & -18.6 \\
$\mathrm{Ca}$ & 110 & 76 & 152 & -76 \\
$\mathrm{Mn}$ & 1.2 & 0.7 & 0.48 & 0.22 \\
$\mathrm{~B}$ & 0.21 & 0.22 & 0.216 & 0.004 \\
$\mathrm{Cu}$ & 0.028 & 0.044 & 0.032 & 0.012 \\
$\mathrm{Fe}$ & 33 & 11 & 1.6 & 9.4 \\
$\mathrm{Zn}$ & 0.81 & 0.22 & 0.216 & 0.004 \\
$\mathrm{Mo}$ & $<0.002$ & 0.011 & 0.032 & -0.021 \\
\hline & & & &
\end{tabular}

\section{Treatments and Experimental Set-Up}

The experimental set-up comprising NFT systems (Fig. 1) and combinations of external MBBR and integrated MBBR was compared in four different treatments: (1) External MBBR only, supplying nitrified biogas digestate (NBD) to the NFT system; (2) Both external and integrated MBBR, (3) integrated MBBR only, with time-scheduled BD inputs and (4) integrated MBBR only, with pH-based BD inputs (Table 2). A commercial inorganic fertilizer for soilless production (Kristalon ${ }^{\mathrm{TM}}$ Indigo + Calcinit ${ }^{\mathrm{TM}}$, Yara, Oslo, Norway) was used as the reference nutrient solution. In monitoring concentrations of ions in hydroponic nutrient solution, measurement of electrical conductivity (EC) in the nutrient solution is a standard method. In the present study, the reference nutrient solution was diluted to the same EC as the BD used in the experiment (Table 2).
Initial volume was $12 \mathrm{~L}$ in the nutrient solution tank (Fig. 1) for all treatments. Input of BD into NFT systems was $6 \mathrm{~L}$ week $^{-1}$ for all treatments except treatment 4 (see Table 2). Input of BD in treatment 4 was controlled by an automatic $\mathrm{pH}$ monitoring device (HAOSHI $\mathrm{pH}$-electrode (Shanghai, China), which added $20 \mathrm{~mL}$ of BD when the $\mathrm{pH}$ reading was below 5.8. Reading interval for $\mathrm{pH}$ in treatment 4 was 20 min. Input of BD in treatment 3 was performed at midday on Monday, Wednesday, and Friday throughout the cultivation period.

Each replicate consisted of one separate NFT system including gullies, tank and integrated MBBR if applicable, and four replicates per treatment were randomized in blocks, where each block contained one replicate each of treatments $1-4$.

Table 2 Treatments with varying strategies for nitrification of filtered and diluted anaerobic digestate tested in the present study. In treatments 1 and 2, the digestate was nitrified in an external moving-bed-biofilm-reactor (MBBR) prior to use

\begin{tabular}{lllll}
\hline Treatment & External MBBR & Integrated & Digestate input frequency & Digestate input volume \\
\hline 1 & & MBBR & \\
2 & Yes & No & $1-3$ times week $^{1}$ & $6 \mathrm{~L} \mathrm{week}^{-1}$ \\
3 & Yes & Yes & $1-3$ times week $^{-1}$ & $6 \mathrm{~L} \mathrm{week}^{-1}$ \\
4 & No & Yes & 3 times week $^{-1}$ & $2 \mathrm{~L} \mathrm{per} \mathrm{occasion}$ \\
5 & No & Yes & Input when pH $<5.8$ & $20 \mathrm{~mL} \mathrm{per} \mathrm{occasion}$ \\
& Conventional hydroponics system with inorganic fertilizer & & \\
\hline
\end{tabular}

In treatments 3 and 4 , there was no nitrification step prior to use in the growing systems 


\section{Measurements}

The EC and $\mathrm{pH}$ values in solution were measured with a combined EC and pH meter (HQ440d Multi, Hach, Loveland, USA) on three times per week. In treatment 3, pH measurement was repeated $1.5 \mathrm{~h}$ after addition of BD. The electrode of the continuous $\mathrm{pH}$ monitoring device in treatment 4 was submerged in the digestate solution and controlled a $12 \mathrm{~V}$ water pump for automatic $\mathrm{pH}$ adjustment in $\mathrm{BD}$ through an Arduino pH-controller (Arduino, Open source hardware).

Analysis of ammonium-nitrogen $\left(\mathrm{NH}_{4}-\mathrm{N}\right)$ and nitratenitrogen $\left(\mathrm{NO}_{3}-\mathrm{N}\right)$ in $\mathrm{BD}$ was performed through continuous flow analysis (QuAAtro) prior to growth trials, which was performed by an accredited laboratory for fertilizer analysis (LMI AB, Helsingborg, Sweden). During the growth trials, ammonium concentration was measured with a Hach DR1900 spectrophotometer with ammonium cuvettes (Hach LCK 303, Loveland, USA). The concentrations of phosphorus, potassium, calcium, magnesium, sulfur, iron, manganese, boron, copper, zinc, and molybdenum in $\mathrm{BD}$ were determined by LMI AB, using inductively coupled plasma optical emission spectrometry (ICP-OES).

The mineral content in bok choy plants was measured by an accredited laboratory (Eurofins AB, Kristianstad, Sweden), using atomic absorption spectrophotometry (ASD) according to the standardized method by Nordic Committee on Food Analysis (NMKL 161). Fresh weight of shoots was measured directly after harvest and dry weight after drying in a drying cabinet at $60^{\circ} \mathrm{C}$ for 3 days.

\section{Statistics and Treatment of Data}

Data from biometric analysis, water content and nutrient concentrations were tested for differences using analysis of variance (ANOVA) followed by Tukey's multiple comparison test, and $\mathrm{p}<0.05$ considered as significant (Minitab v. 16, Mintab inc. State College PA USA).

\section{Results and Discussion}

The possibility of using BD for hydroponic production has earlier been addressed from a circular bioeconomy perspective by Ronga et al. [2]. The results obtained in the present study further supports this use and suggest that hydroponic production of leafy vegetables based on BD might be a viable solution for problems with digestate disposal from biogas production and increasing demand for food. Any positive effects on crop quality, regarding shoot mineral content and water content, would add to the value of such a production system.

\section{Nitrification Reactor Set-Up and Influence on pH and Electrical Conductivity}

Comparison of treatment 1 (external MBBR) and treatment 2 (integrated MBBR), both using nitrified BD (see Table 2) revealed that the $\mathrm{pH}$ in treatment 1 was initially higher than in treatment 2 and increased slightly until 15 days after transplanting, after which it decreased rapidly. During the same time period $\mathrm{pH}$ increased in treatment 2 with integrated MBBR, as seen in Fig. 2A. The lower pH during the first half of the cultivation period in treatment 2 , where the MBBR was integrated into the system was probably due to a higher grade of nitrification in the two-stage sequential MBBR set-up in treatment 2, giving a longer contact time with MBBR.

The changes in $\mathrm{pH}$ starting approximately 15 days after transplanting in treatments 1 and 2 were presumably due to plant uptake of the different inorganic nitrogen forms and subsequent excretion of carbonate ions, hydroxides or protons by the plant root, influencing the solution $\mathrm{pH}[23,26]$. The increasing $\mathrm{pH}$ in treatment 2 may be attributable to plant nitrate uptake due to the higher nitrate content with use of integrated MBBR, while the decreasing $\mathrm{pH}$ in treatment 1 can be the result of the higher ammonium concentration due to lack of an integrated nitrification reactor and thus higher plant ammonium uptake. A similar pattern of decreasing $\mathrm{pH}$ was observed after direct input of BD to the NFT system ( $\mathrm{pH}$ 8.2) not subjected to any nitrification, thus with high ammonium concentration (data not shown).

Increasing root mass and an associated continuous increment in total root surface area in the NFT gully during cultivation presumably also contributed to the decrease in $\mathrm{pH}$, as a result of growth of nitrifying bacteria attached to root surfaces. This effect of nitrifying bacteria has been observed previously in bok choy and tomato cultures in a floating raft aquaponic system [27]. That study demonstrated that large and increasing root surface area is highly important for nitrification in aquaponic systems that lack a nitrification reactor, and is correlated with increasing nitrification over time in such systems.

Input of $2 \mathrm{~L}$ of un-nitrified $\mathrm{BD}$ in treatment 3 (integrated MBBR) led to a rapid increase in $\mathrm{pH}$ to approximately $\mathrm{pH} 7$, after which the $\mathrm{pH}$ decreased to $\mathrm{pH}$ 5.0-5.5 due to nitrification in the MBBR (Fig. 2B). From a commercial perspective focusing on production parameters, this large variation in $\mathrm{pH}$ in a hydroponic system is undesirable, as plant nutrient uptake might be affected. The use of a control device to keep the $\mathrm{pH}$ to a fixed value of 5.8 in treatment 4 was successful (Fig. 2C, black line). However, a mean feeding rate of $1.5 \mathrm{~L}$ diluted BD per day was required. Treatments 

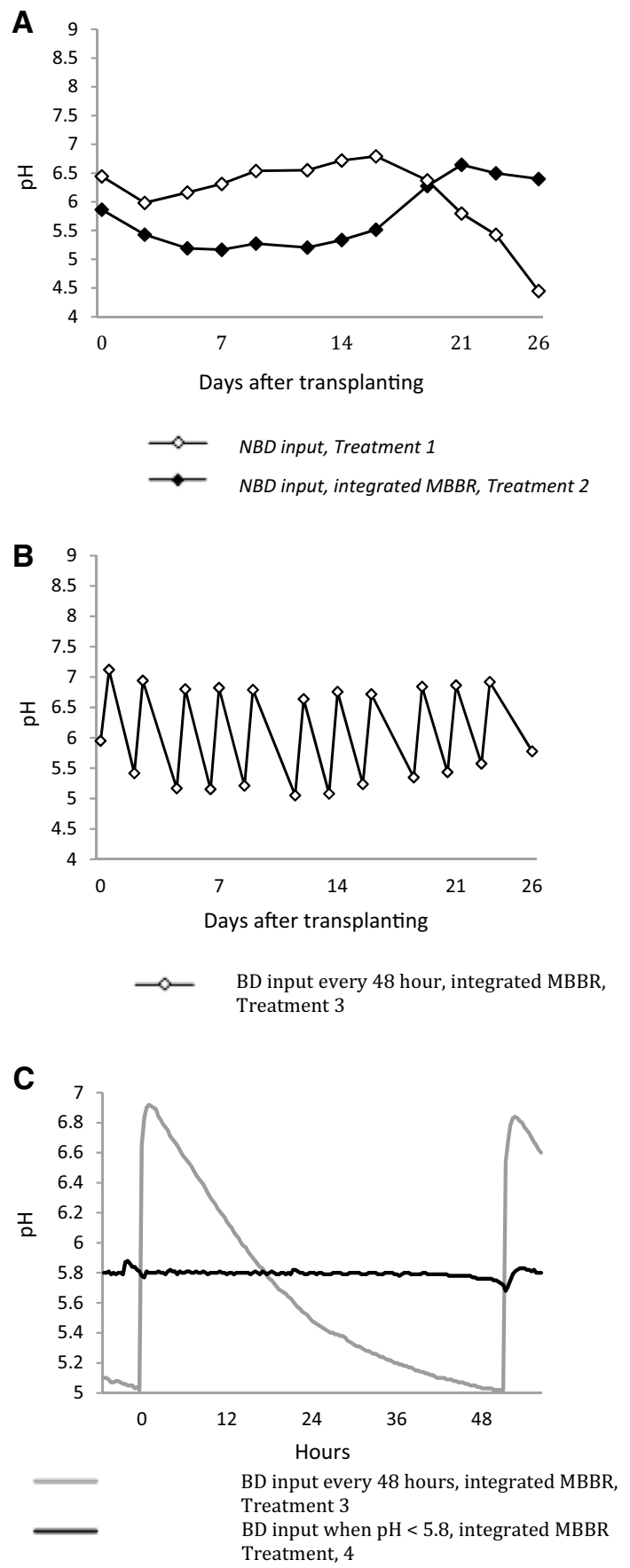

Fig. 2 Dynamics of $\mathrm{pH}$ in the different treatments A Treatment 1 and 2; nitrified biogas digestate (NBD) input from external moving bed biofilm reactor (MBBR). B Treatment 3; integrated MBBR and biogas digestate (BD) input every $48 \mathrm{~h}$. C Monitored $\mathrm{pH}$ values (reading every $20 \mathrm{~min}$ ) from treatments with integrated MBBR but different BD input methods: (i) treatment 3 ( $2 \mathrm{~L}$ input every $48 \mathrm{~h}$ ), (ii) treatment $4(0.02 \mathrm{~L}$ input when $\mathrm{pH}$ was $<5.8)$

1,2 , and 3 were fed with $6 \mathrm{~L}$ digestate per week, which led to a relatively stable volume of nutrient solution in the reservoir tank (10-15 $\left.\mathrm{L} \mathrm{system}^{-1}\right)$, while addition of $10.5 \mathrm{~L}$ digestate week ${ }^{-1}$ in treatment 4 led to considerable accumulation of digestate solution. In order to achieve $\mathrm{pH}$ control through continuous integrated nitrification and automated input of $\mathrm{BD}$, the amount of $\mathrm{BD}$ for $\mathrm{pH}$ control needs to be further optimized and comply with other cultivation system variables, namely operational volume of nutrient solution in the reservoir tank and EC. As can be seen in the results for pH dynamics (Fig. 2), investigation of the effects of different nitrification strategies is important for designing wellfunctioning BD-based hydroponic systems. This is due to the effects on $\mathrm{pH}$ from $\mathrm{BD}$ input, from nitrification of $\mathrm{BD}$ within the cultivation system and the plants uptake of different inorganic nitrogen forms.

A sufficient concentration of plant nutrients is important for the productivity and economic feasibility of a hydroponic system. Nutrient deficiency has been shown to partly explain the lower productivity in organic hydroponic systems than in conventional hydroponic production [28]. As mentioned, measurement of EC is used as a standard method to monitor this parameter in hydroponic nutrient solution.

\section{Plant Growth}

In first week after transplantation, all BD treatments showed considerably slower growth (determined visually) than the reference treatment. Such a trend has also been noted in earlier trials by our research group with basil and lettuce (unpublished data). It seems to relate to a need for root acclimatization when seedlings are moved from a pure inorganic synthetic solution to a BD solution. Prolonging the cultivation period by seven days (from 21 to 28 days) considerably increased the shoot fresh and dry weight (Fig. 3). Thus, any improvements in crop quality and environmental advantages deriving from BD-based hydroponic production may compensate for the longer cultivation time needed to reach the same yields as in conventional hydroponics (reference system). This extended period could probably be shortened by optimization of the $\mathrm{BD}$ system regarding cultivation system parameters such as $\mathrm{pH}$ and EC. The optimal EC for hydroponic cultivation of bok choy from transplanting to harvest, determined experimentally, is $2.0 \mathrm{mS} \mathrm{cm}{ }^{-1}$ [29], which is in range required by several other leafy vegetable species. It can be concluded that use of BD as a nutrient source resulted in EC levels that were well suited for hydroponic production when diluted to a desired nitrogen concentration.

It was notable that there was no significant difference in shoot dry weight between treatment 4 (with $\mathrm{BD}$, an integrated MBBR, and continuous $\mathrm{pH}$ regulation) and the inorganic commercial fertilizer reference (Fig. 3B). Comparing treatments with input of BD with and without MBBR and with input of BD without prior nitrification and with MBBR revealed significant differences between treatments in terms of shoot fresh weight, but not shoot dry weight, in the trials 

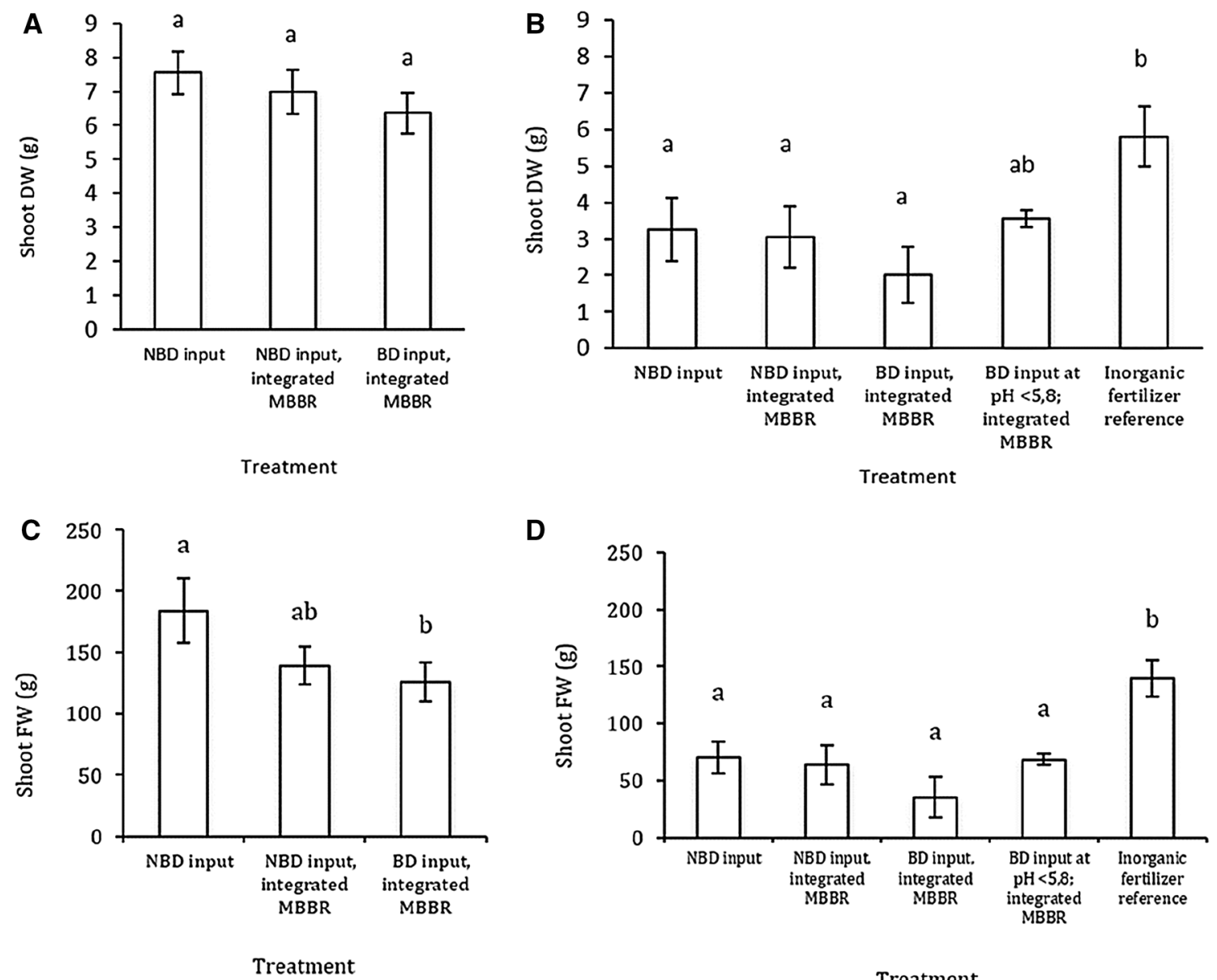

Treatment

Treatment

Fig. 3 Shoot dry and fresh weight in (A, C) treatments 1, 2 and 3 with an extended 28-day growth period and $(\mathbf{B}, \mathbf{D})$ treatments 1-5 with a conventional 21-day growth period. Means with differ- ent letters are significantly different according to Tukey's HSD test, $\mathrm{p}<0.05$. $\mathrm{MBBR}=$ moving bed biofilm reactor; $\mathrm{f}-\mathrm{BD}=$ biogas digestate; $\mathrm{f}-\mathrm{NBD}=$ nitrified biogas digestate
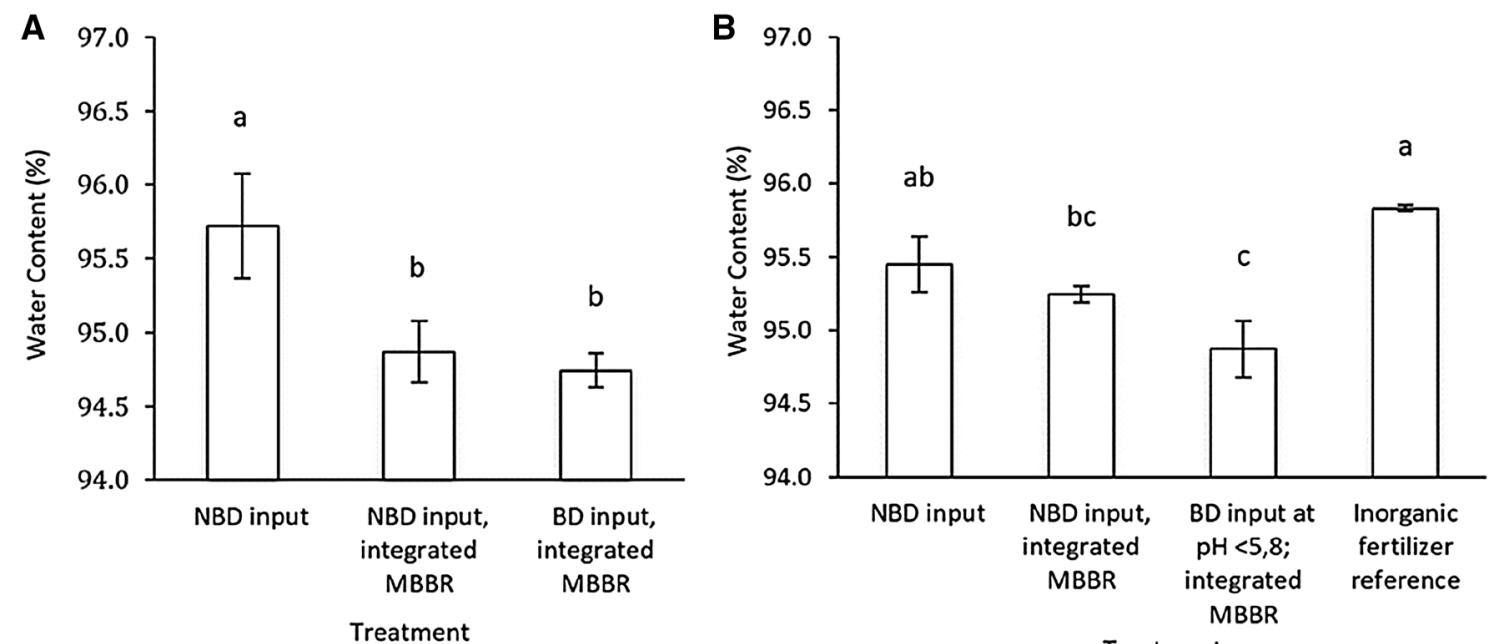

Fig. 4 Shoot water content with A 28-day growing period and B 21-day growing period. Means with different letters are significantly different according to Tukey's HSD test, $\mathrm{p}<0.05$. MBBR $=$ moving bed biofilm reactor; $\mathrm{BD}=$ biogas digestate; $\mathrm{NBD}=$ nitrified biogas digestate 
with a 28-day growing period (Fig. 3A, C). This variation in shoot dry weight compared with fresh weight was the result of differences in shoot water content between treatments (Fig. 4). Shoot fresh and dry weight in the trials with a 21-day growing period did not differ significantly among the BD-based treatments (Fig. 3B, D).

\section{Water and Mineral Aspects}

As mentioned, there were significant differences in the water content of the shoots between the treatments (Fig. 4). Shoot water content was generally lower in treatments with an integrated MBBR (treatments 2 and 4, Tab. 2) than in the treatment with an external MBBR only (treatment 1 ) or in the inorganic reference. However, the actual difference in plant water content between the treatment with the lowest shoot water content and that with the highest (inorganic reference) was only approximately $1 \%$ (Fig. 4B). Thus, despite being of interest from a plant physiology perspective, the commercial impact of this difference is probably minor.

Significant differences in shoot mineral content were observed between the different treatments and the reference (Table 3). However, it should be pointed out that the shoot mineral content data did not suggest growth limitation due to nutrient deficiency in any of the treatments. From a nutritional perspective, the minerals iron and zinc have been pointed out as important [30]. It is therefore interesting that the iron and zinc content per $100 \mathrm{~g}$ fresh weight were significantly higher in plant shoots grown in BD-based nutrient solution than in pure inorganic solution (Fig. 5). Sulfur-containing glucosinalates are important secondary metabolites in Brassica species from a human nutrition perspective [31]. The significantly higher sulfur content per $100 \mathrm{~g}$ fresh weight in all BD treatments compared with the inorganic reference is interesting, as this may indicate higher glucosinolate content in plants grown in BD-based hydroponic cultivation (Fig. 5). However, this has to be further investigated.

The concentrations of phosphorus, manganese, zinc and copper in hydroponically grown lettuce have been shown to increase with increasing ammonium:nitrate ratio, presumably due to $\mathrm{pH}$ effects from plant uptake of ammonium [32]. Thus, differences in $\mathrm{pH}$ and ammonium:nitrate ratio in the treatments in the present study can be assumed to be one factor behind the significant differences in shoot mineral content. Replacement of part of the nitrate with glutamic acid or glutamine in hydroponic cultivation of bok choy has been suggested as a means of reducing the nitrate content and increasing the macronutrient content in the leaves [33]. Thus, the observed differences in biomass in the present study may also be attributable to the amino acid content in the BD treatments.

\section{Conclusions}

This study showed that plant-derived anaerobic biodigestate is a valuable nutrient solution when sieved, diluted to an appropriate ammonium concentration, and then subjected to controlled nitrification before and/or during its use in recirculating hydroponic cultivation. Considering biocircular economy aspects of the system and the possibly higher crop quality, satisfactory yields were obtained in BD-based hydroponic cultivation of bok choy. Increasing the cultivation time by less than one week gave yields equal to those in conventional hydroponic production.

The strategy used for nitrification and nutrient solution feeding to the system affected the $\mathrm{pH}$ dynamics, with $\mathrm{pH}$ decreases during nitrification and rapid $\mathrm{pH}$ increases on adding unnitrified BD to the system. Through automation,
Table 3 Nutrient concentrations in plant shoots (dry matter) in treatments 1-4 and the reference (treatment 5) (see Table 1)

\begin{tabular}{|c|c|c|c|c|c|c|c|c|c|c|c|}
\hline Nutrient & Units & 1 & & 2 & & 3 & & 4 & & $\begin{array}{l}\text { Refer } \\
\text { ence }\end{array}$ & \\
\hline $\mathrm{N}$ & $\%$ dry weight & 6.4 & a & 7.4 & a & 6.7 & $\mathrm{a}$ & 8.1 & $\mathrm{a}$ & 8.0 & $\mathrm{a}$ \\
\hline $\mathrm{P}$ & $"$ & 0.81 & $\mathrm{a}$ & 0.84 & $\mathrm{a}$ & 0.73 & $\mathrm{a}$ & 0.81 & $\mathrm{a}$ & 0.75 & $\mathrm{a}$ \\
\hline K & $"$ & 8.23 & $a b$ & 8.80 & $\mathrm{ad}$ & 6.80 & $\mathrm{c}$ & 7.23 & $\mathrm{bc}$ & 9.93 & d \\
\hline $\mathrm{Ca}$ & $"$ & 1.6 & $\mathrm{a}$ & 2 & $\mathrm{~b}$ & 1.9 & $\mathrm{~b}$ & 1.47 & a & 2.77 & $\mathrm{c}$ \\
\hline $\mathrm{Mg}$ & $"$ & 0.31 & $\mathrm{a}$ & 0.38 & $\mathrm{~b}$ & 0.37 & $\mathrm{~b}$ & 0.27 & $\mathrm{c}$ & 0.37 & $\mathrm{~b}$ \\
\hline S & $"$ & 1.2 & $a b$ & 1.4 & $\mathrm{~b}$ & 1.1 & ac & 1.1 & $\mathrm{ac}$ & 0.9 & $\mathrm{c}$ \\
\hline $\mathrm{Fe}$ & $\mathrm{mg} \mathrm{kg}^{-1}$ & 84 & $a b$ & 97 & b & 86 & $a b$ & 93 & $\mathrm{~b}$ & 63 & $\mathrm{a}$ \\
\hline $\mathrm{Mn}$ & $"$ & 163 & $\mathrm{a}$ & 157 & $a b$ & 117 & $\mathrm{~b}$ & 160 & $\mathrm{a}$ & 157 & $a b$ \\
\hline B & $"$ & 45 & $\mathrm{ac}$ & 47 & $\mathrm{a}$ & 52 & $\mathrm{ab}$ & 59 & b & 38 & c \\
\hline $\mathrm{Cu}$ & $"$ & 4.7 & $\mathrm{a}$ & 4.4 & $a b$ & 3.5 & $\mathrm{~b}$ & 3.5 & $\mathrm{~b}$ & 3.8 & $a b$ \\
\hline $\mathrm{Zn}$ & $"$ & 87 & $\mathrm{a}$ & 75 & $\mathrm{a}$ & 45 & b & 77 & $\mathrm{a}$ & 70 & $\mathrm{a}$ \\
\hline Мo & $"$ & 7.7 & $\mathrm{a}$ & 8.6 & $\mathrm{a}$ & 6.5 & $a b$ & 5.6 & $a b$ & 3.5 & $\mathrm{~b}$ \\
\hline
\end{tabular}

Means with different letters are significantly different according to Tukey's HSD test, $\mathrm{p}<0.05$ 
Fig. 5 Plant mineral content in shoot biomass $\left(\mathrm{mg} 100 \mathrm{~g}^{-1}\right.$ fresh weight $\mathrm{FW})^{-1}$ in treatments $1-4$ and the reference system in a 21-day growing trial. Means with different letters are significantly different according to Tukey's HSD test, $\mathrm{p}<0.05$
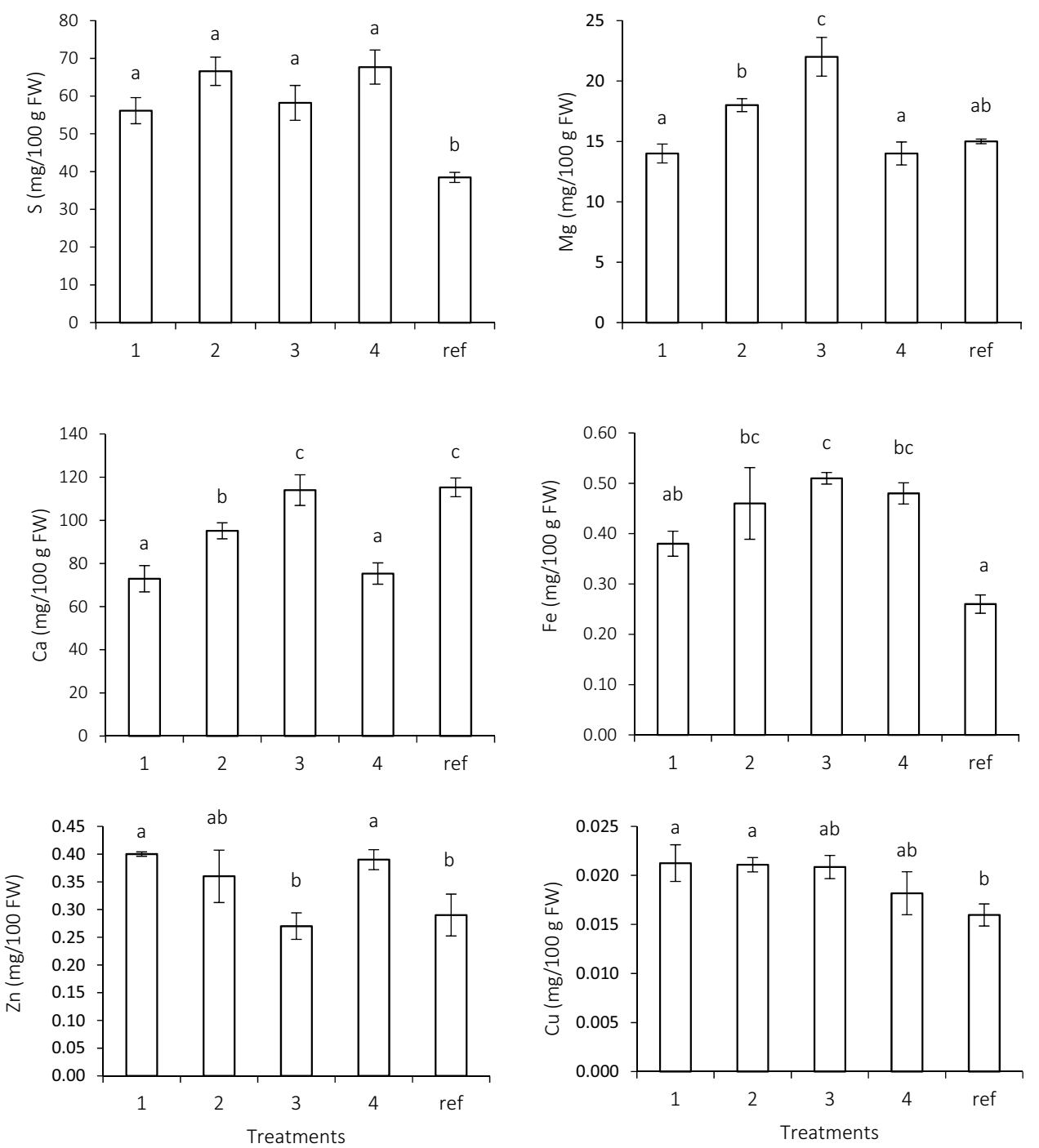

solution $\mathrm{pH}$ can be set to a desired value in a hydroponics system using only an integrated nitrification reactor and addition of unnitrified digestate. This enables $\mathrm{pH}$ control without addition of mineral acids or bases.

Acknowledgements Open access funding provided by Swedish University of Agricultural Sciences. This work was partly funded by Familjen Kamprads stiftelse (The Kamprad Family Foundation) and the Swedish research council for sustainable development (FORMAS), which are gratefully acknowledged. The authors also want to thank Jordberga biogas production facility (Sweden) and Gasum AB for supplying the project with digestate, and Källby water treatment (Lund, Sweden) facility for providing active sludge for nitrification bacteria inoculation.

Funding This study was funded by The Kamprad Family foundation and by Formas (Grant 2018-01845).

\section{Compliance with Ethical Standards}

Conflict of interest All authors declare that they have no conflict of interest.

Ethical Approval This article does not contain any studies with human participants or animals performed by any of the authors.

Open Access This article is licensed under a Creative Commons Attribution 4.0 International License, which permits use, sharing, adaptation, distribution and reproduction in any medium or format, as long as you give appropriate credit to the original author(s) and the source, provide a link to the Creative Commons licence, and indicate if changes were made. The images or other third party material in this article are included in the article's Creative Commons licence, unless indicated otherwise in a credit line to the material. If material is not included in the article's Creative Commons licence and your intended use is not permitted by statutory regulation or exceeds the permitted use, you will need to obtain permission directly from the copyright holder. To view a copy of this licence, visit http://creativecommons.org/licenses/by/4.0/. 


\section{References}

1. Puyol, D., Batstone, D.J., Hülsen, T., Astals, S., Peces, M., Krömer, J.O.: Resource recovery from wastewater by biological technologies: opportunities, challenges, and prospects. Front. Microbiol. 7, 2106 (2017). https://doi.org/10.3389/fmicb .2017 .00998

2. Ronga, D., Setti, L., Salvarani, C., De Leo, R., Bedin, E., Pulvirenti, A., Milc, J., Pecchioni, N., Francia, E.: Effects of solid and liquid digestate for hydroponic baby leaf lettuce (Lactuca sativa L.) cultivation. Sci. Hortic. (Amsterdam) 244, 172-181 (2019). https://doi.org/10.1016/j.scienta.2018.09.037

3. Stiles, W.A.V., Styles, D., Chapman, S.P., Esteves, S., Bywater, A., Melville, L., Silkina, A., Lupatsch, I., Fuentes Grünewald, C., Lovitt, R., Chaloner, T., Bull, A., Morris, C., Llewellyn, C.A.: Using microalgae in the circular economy to valorise anaerobic digestate: challenges and opportunities. Bioresour. Technol. 267, 732-742 (2018). https://doi.org/10.1016/j.biortech.2018.07.100

4. Grigatti, M., Boanini, E., Cavani, L., Ciavatta, C., Marzadori, C.: Phosphorus in digestate-based compost: chemical speciation and plant-availability. Waste Biomass Valoriz. 6, 481-493 (2015). https://doi.org/10.1007/s12649-015-9383-2

5. Scarlat, N., Dallemand, J.F., Monforti-Ferrario, F., Nita, V.: The role of biomass and bioenergy in a future bioeconomy: policies and facts. Environ. Dev. 15, 3-34 (2015). https://doi.org/10.1016/j. envdev.2015.03.006

6. Stoknes, K., Wojciechowska, E., Tesfamichael, A.A., Jasińska, A., Gulliksen, A.: Growing vegetables in the circular economy; cultivation of tomatoes on green waste compost and food waste digestate. Acta Hortic. (2018). https://doi.org/10.17660/actahortic .2018 .1215 .71

7. Möller, K., Müller, T.: Effects of anaerobic digestion on digestate nutrient availability and crop growth: a review. Eng. Life Sci. 12, 242-257 (2012). https://doi.org/10.1002/elsc.201100085

8. Sheets, J.P., Yang, L., Ge, X., Wang, Z., Li, Y.: Beyond land application: Emerging technologies for the treatment and reuse of anaerobically digested agricultural and food waste. Waste Manag. 44, 94-115 (2015). https://doi.org/10.1016/j.wasman.2015.07.037

9. Rehl, T., Müller, J.: Life cycle assessment of biogas digestate processing technologies. Resour. Conserv. Recycl. 56, 92-104 (2011). https://doi.org/10.1016/j.resconrec.2011.08.007

10. Nkoa, R.: Agricultural benefits and environmental risks of soil fertilization with anaerobic digestates: a review. Agron. Sustain. Dev. 34, 473-492 (2014). https://doi.org/10.1007/s13593-013-0196-Z

11. Porter, I.J.: What is driving industry tipping points from open field to hydroponics. ICESC2015 Hydroponics Aquaponics Gold Coast 1176, 129-136 (2015). https://doi.org/10.17660/ActaHortic .2017.1176.17

12. Raviv, M.: Should we use soilless media in organic greenhouses? Acta Hortic. 1164, 535-540 (2017). https://doi.org/10.17660/ ActaHortic.2017.1164.70

13. Kikuchi, Y., Kanematsu, Y., Yoshikawa, N., Okubo, T., Takagaki, M.: Environmental and resource use analysis of plant factories with energy technology options: a case study in Japan. J. Clean. Prod. 186, 703-717 (2018). https://doi.org/10.1016/j.jclep ro.2018.03.110

14. Zabel, P., Bamsey, M., Schubert, D., Tajmar, M.: Review and analysis of over 40 years of space plant growth systems. Life Sci. Space Res. 10, 1-16 (2016). https://doi.org/10.1016/j. 1ssr.2016.06.004

15. Liedl, B.E., Cummins, M., Young, A., Williams, M.L., Chatfield, J.M.: Hydroponic lettuce production using liquid effluent from poultry waste bioremediation as a nutrient source, in: VII International Symposium on Protected Cultivation in Mild Winter Climates: Production, Pest Management and Global Competition
659. pp 721-728 (2004) https://doi.org/10.17660/actahortic .2004 .659 .93

16. Mackowiak, C.L., Garland, J.L., Strayer, R.F., Finger, B.W., Wheeler, R.M.: Comparison of aerobically-treated and untreated crop residue as a source of recycled nutrients in a recirculating hydroponic system. Adv. Space Res. 18, 281-287 (1996). https:// doi.org/10.1016/0273-1177(95)00817-X

17. Shinohara, M., Aoyama, C., Fujiwara, K., Watanabe, A., Ohmori, H., Uehara, Y., Takano, M.: Microbial mineralization of organic nitrogen into nitrate to allow the use of organic fertilizer in hydroponics. Soil Sci. Plant Nutr. 57, 190-203 (2011). https:// doi.org/10.1080/00380768.2011.554223

18. Stoknes, K., Scholwin, F., Krzesiński, W., Wojciechowska, E., Jasińska, A.: Efficiency of a novel "Food to waste to food" system including anaerobic digestion of food waste and cultivation of vegetables on digestate in a bubble-insulated greenhouse. Waste Manag. 56, 466-476 (2016). https://doi.org/10.1016/j.wasma n.2016.06.027

19. Suhl, J., Dannehl, D., Kloas, W., Baganz, D., Jobs, S., Scheibe, G., Schmidt, U.: Advanced aquaponics: evaluation of intensive tomato production in aquaponics vs. conventional hydroponics. Agric. Water Manag. 178, 335-344 (2016). https://doi.org/10.1016/j. agwat.2016.10.013

20. Raviv, M., Lieth, J.H.: Soilless Culture: Theory and Practice. Elsevier, London (2007). https://doi.org/10.1016/b978-0-444-52975 $-6 . x 5001-1$

21. Takemura, K., Endo, R., Shibuya, T., Kitaya, Y.: Modifications of concentrations of plant macronutrient ions in digestate from anaerobic digestion during nitrification processes. J. Residuals Sci. Technol. 13, 207-214 (2016). https://doi.org/10.12783/ issn. 1544-8053/13/3/4

22. Wang, H.-J., Wu, L.-H., Tao, Q.-N., Miller, D.D., Welch, R.M.: Glutamine nitrogen and ammonium nitrogen supplied as a nitrogen source is not converted into nitrate nitrogen of plant tissues of hydroponically grown pak-choi (Brassica chinensis L.). J. Food Sci. 74, T21-T23 (2009). https://doi.org/10.111 1/j.1750-3841.2008.01023.x

23. Marschner, H.: Mineral nutrition of higher plants. Academic Press, London (1995). https://doi.org/10.1016/b978-0-12-47354 2-2.x5000-7

24. Botheju, D., Svalheim, O., Bakke, R.: Digestate nitrification for nutrient recovery. Open Waste Manag. J. (2010). https://doi. org/10.2174/1876400201003010001

25. Gasum Jordberga.: Produktblad Ekologisk Biogödsel dec 2017feb 2018. Gasum. (in Swedish) (2018)

26. Lea-Cox, J.D., Berry, W.L., Stutte, G.W., Wheeler, R.M.: Nutrient dynamics and $\mathrm{pH} /$ charge-balance relationships in hydroponic solutions. Acta Hortic. (1999). https://doi.org/10.17660/actahortic .1999 .481 .25

27. Hu, Z., Lee, J.W., Chandran, K., Kim, S., Brotto, A.C., Khanal, S.K.: Effect of plant species on nitrogen recovery in aquaponics. Bioresour. Technol. 188, 92-98 (2015). https://doi.org/10.1016/j. biortech.2015.01.013

28. Wortman, S.E.: Crop physiological response to nutrient solution electrical conductivity and $\mathrm{pH}$ in an ebb-and-flow hydroponic system. Sci. Hortic. (Amsterdam) 194, 34-42 (2015). https://doi. org/10.1016/j.scienta.2015.07.045

29. Cho, Y.Y., Son, J.E.: Effects of electrical conductivity on growth and yield of hydroponically-grown pak-choi (Brassica campestris ssp. chinensis). Hortic. Environ. Biotechnol. 48, 97-101 (2007)

30. White, P.J., Broadley, M.R.: Biofortification of crops with seven mineral elements often lacking in. New Phytol. 182, 49-84 (2009). https://doi.org/10.1111/j.1469-8137.2008.02738.x

31. Avato, P., Argentieri, M.P.: Brassicaceae: a rich source of health improving phytochemicals. Phytochem. Rev. 14, 1019-1033 (2015). https://doi.org/10.1007/s11101-015-9414-4 
32. Savvas, D., Passam, H.C., Olympios, C., Nasi, E., Moustaka, E., Mantzos, N., Barouchas, P.: Effects of ammonium nitrogen on lettuce grown on pumice in a closed hydroponic system. HortScience 41, 1667-1673 (2006). https://doi.org/10.21273/hortsci.41.7.1667

33. Wang, H., Wu, L., Zhu, Y., Tao, Q.: Growth, nitrate accumulation, and macronutrient concentration of pakchoi as affected by external nitrate-N: Amino acid-N ratio. J. Plant Nutr. 31, 1789-1799 (2008). https://doi.org/10.1080/01904160802325248
Publisher's Note Springer Nature remains neutral with regard to jurisdictional claims in published maps and institutional affiliations. 